\title{
Use of beta regression to estimate the volumetric yield coefficient in logs of native species of the legal amazon
}

\author{
Zaira Morais dos Santos Hurtado de MENDOZA ${ }^{1 *}$, Pedro Hurtado de Mendoza BORGES ${ }^{2}$, \\ Pedro Hurtado de Mendoza MORAIS², Maísa Pavani dos Santos ELIAS ${ }^{1}$ \\ ${ }^{1}$ Faculdade de Engenharia Florestal, Universidade Federal de Mato Grosso, Cuiabá, Mato Grosso, Brasil. \\ ${ }^{2}$ Faculdade de Agronomia e Zootecnia, Universidade Federal de Mato Grosso, Cuiabá, Mato Grosso, Brasil. \\ E-mail: zairamorais09@gmail.com
}

Recebido em junho/2018; Aceito em dezembro/2018.

\begin{abstract}
The research was developed at a logging site within the Legal Amazon and its main objective was to quantify the percent yield of the logging process for each species. In addition, the objective also included verifying the possibility of using the log's conicity to estimate their yield. Nine (9) logs were randomly selected from each of the 19 native species available at the sawmill, totalling 171 studied logs. The adopted methodology was based on a resolution from the Environmental National Council (CONAMA). Using the Software R, one beta regression model was developed based on the yield and conicity data. In the joint analysis of the data, the coefficient of volumetric yield (CVY), of all species was above the minimum required by current legislation. The use of the species and log's conicity as a functional dependence to estimate the yield of sawn wood showed high reliability, which justifies its application. Thus, the obtained statistical model may become a useful tool for the planning and management of the processing of logs from native species of the Legal Amazon.
\end{abstract}

Keywords: sawn wood, volume modeling, forest planning.

\section{Uso da regressão beta para estimar o coeficiente de rendimento volumétrico em toras de espécies nativas da amazônia legal}

\begin{abstract}
RESUMO: A pesquisa foi desenvolvida em uma madeireira, situada dentro da Amazônia Legal e teve como objetivo principal quantificar, por espécie, o coeficiente de rendimento volumétrico do desdobro de toras. Além disso objetivou-se também, verificar a possibilidade do uso da conicidade da tora para estimativa do referido rendimento. Foram selecionadas aleatoriamente 9 toras de cada uma das 19 espécies nativas, disponíveis no pátio da indústria, totalizando 171 toras estudadas. A metodologia adotada teve como referência as Resoluções do Conselho Nacional de Meio Ambiente (CONAMA). Com base nos dados do coeficiente de rendimento e da conicidade de cada tora foi desenvolvido um modelo de regressão beta, utilizando-se o Software R. Na análise conjunta dos dados, o coeficiente de rendimento volumétrico (CRV) de todas as espécies, superou o mínimo exigido pela legislação vigente. O uso da espécie e da conicidade da tora, como dependência funcional, para a estimativa do coeficiente de rendimento em madeira serrada mostrou elevada confiabilidade, o que justifica sua aplicação. Dessa forma, o modelo estatístico obtido poderá servir como uma ferramenta útil para o planejamento e gestão do processamento de toras, procedentes de espécies nativas da Amazônia Legal.

Palavras-chave: madeira serrada, volumetria, planejamento florestal.
\end{abstract}

\section{INTRODUCTION}

The Legal Amazon currently includes nine Brazilian states, whose main economic activities are agriculture, cattle ranching, and vegetal extractivism, this latter sector highlighting the exploitation of native forests to produce sawn and laminated wood. However, the timber industries operating in this region are mostly companies that rely on reduced capital and incipient forest management, in addition to having obsolete, poorly kept equipment and unskilled labor (MURARA JUNIOR et al., 2013). All these factors, whether individually or collectively, directly influence the productivity of sawmills, since they process them inefficient, low yielding, noneconomical and generating large amounts of unexplored waste and by-products (BUFALINO et al., 2012).

Despite its retracted technological development, the mechanical processing of wood has been contributing for several decades to the regional economy of some Brazilian states and municipalities, and deserves research and improvements so that it can organize and gain competitiveness in the market. Along this line of research, the process characterization, based on industrial performance (yield), is a useful tool that may generate forecasts, estimates and probabilities assisting in decision-making (MENDOZA et al., 2010). There are different ways of evaluating the performance of a sawmill, but the yield of lumber produced variable is widely used for this purpose, regardless of the criteria adopted for the economic analysis of this enterprise type. The yield of a sawmill can be mathematically defined as the ratio between the volume of log lumber and the volume of lumber produced at the end of the process, and this can be expressed in units of volume or in percentage (VITAL, 2008). Although easily calculated, this yield can be altered by different factors. The diameter of the logs, machinery, technological characteristics of the species used, the final product generated and the skill 
qualifications held by the employed labour force can all be highlighted among the main factors that influence yield (GARCIA, 2013).

Along with economic problems, the low yield of lumber also entails environmental problems, since a larger volume of raw material should be consumed to compensate for the low yield and to achieve the industry's production target, consequently producing an increase in waste which would be unavoidable. Therefore, wood optimization should be an obvious concern, both for economic and environmental gains (JUIZO et al., 2014). This concern should be given even more importance in the Amazon region, since according to Melo et al., (2012) the main producers of tropical lumber in our country are concentrated in this region, namely in Pará (45\%) and Mato Grosso (33\%). The quantification of the yield of sawn wood inside the sawmills is still quite laborious, time consuming and in some cases, with little reliability. According to Santos et al. (2017), this situation can be greatly improved, with the use of mathematical models, since they allow obtaining an equation that can estimate with accuracy, the yield of sawnwood for different species.

Based on these considerations, the main objective of this research was to quantify the volumetric yield coefficient of logs from the Legal Amazon, using its geometric measurements, and also to verify the possibility to apply a regression as a mathematical tool to estimate the volumetric yield coefficient in function of the conicity.

\section{MATERIAL AND METHODS}

2.1. Study location, lumber yard description and selection of species

The research was developed at a logging site within the Legal Amazon in a transition area between the cerrado (Brazilian savannah) and the Amazon Forest. The data were collected on site at a medium sized sawmill, located at the following geographic coordinates: $13^{\circ} 02^{\prime} 49.22$ " S and $57^{\circ}$ $05^{\prime} 42.36$ " W.

The studied lumber industry processes between 1000 and $2000 \mathrm{~m}^{3}$ of logs monthly, with an average volume of $850 \mathrm{~m}^{3}$ of sawn products. The main pieces of machinery used by the lumber company include: head saws (standing and circle), log carts, winches, trucks, tractors, trimmers, grinding set, sanders, and several other types of sawing machines. Nineteen (19) native forest species were selected, which were available in the company yard (Table 1), not being informed of its origem. For replicates, nine (9) logs were selected per species, totalling 171 measured logs. The origin of the logs was mentioned as being of forest management, native species of the Legal Amazônia, but it was not clarified if the management was of public forest concessions, own or of third parties. The registration number at IBAMA has not been provided. 2.2. Data collection and evaluation of parameters

\subsection{Data collection and evaluation of parameters}

Data were collected along nine months, as the logs arrived at the sawmill. Before the breakdown of the logs, in order to establish criteria for the classification and selection of logs, the following variables were evaluated: conicity, pith eccentricity, width of largest top crack, roundness and curvature.

After being classified, the logs were marked, measured and prepared for breakdown. The methodology adopted to determine the coefficient of volumetric yield was based on resolutions 411 (BRASIL, 2009) e and 474 (BRASIL, 2016)

from the Environmental National Council (CONAMA).

Table 1. Selected native forest species.

Tabela 1. Espécies florestais nativas selecionadas.

\begin{tabular}{|c|c|c|}
\hline Common name & Scientific name & Family \\
\hline Amarelinho & Platymenia reticulata & $\begin{array}{l}\text { Fabaceae - } \\
\text { Mimosoideae }\end{array}$ \\
\hline Amescla & $\begin{array}{l}\text { Trattinickia } \\
\text { burserifolia }\end{array}$ & Burseraceae \\
\hline Angelim Pedra & $\begin{array}{l}\text { Hymenolobium } \\
\text { petraeum }\end{array}$ & Fabaceae \\
\hline Angelim Saia & Parkia pendula & $\begin{array}{l}\text { Leguminosae- } \\
\text { Mimosoideae }\end{array}$ \\
\hline Bajão & Parkia multijuga & Fabaceae \\
\hline Cambará & Gochnatia polymorpha & Asteraceae \\
\hline Canela & Aniba canelilla & Lauraceae \\
\hline Canelão & $\begin{array}{l}\text { Nectandra } \\
\text { membranacea }\end{array}$ & Lauraceae \\
\hline Cedrinho & Erisma uncinatum & Vochysiaceae \\
\hline $\begin{array}{l}\text { Cedro } \\
\text { Amazonas }\end{array}$ & $\begin{array}{l}\text { Cedrelinga } \\
\text { catenaeformis }\end{array}$ & Mimosaceae \\
\hline Champanhe & Dipteryx odorata & Leguminosae \\
\hline Copaíba & Copaifera multijuga & Cesalpiniaceae \\
\hline Farinha Seca & Albizia hasslerii & Fabaceae \\
\hline Faveiro & Peltophorum dubium & Fabaceae \\
\hline Garapeira & Apuleia Ieiocarpa & Leguminosae \\
\hline Guanandi & $\begin{array}{l}\text { Calophyllum } \\
\text { brasiliense }\end{array}$ & Clusiaceae \\
\hline Itaúba & Mezilaurus itauba & Lauraceae \\
\hline Mandioqueira & Qualea albiflora & Vochysiaceae \\
\hline Peroba Cupiúba & Goupia glabra & Goupiaceae \\
\hline
\end{tabular}

Fonte: Lorenzi (2008).

Besides measuring the circumference perimeters and the diameters of the ends of the logs, their length and the thickness of their bark were also measured. All measurements were taken with the aid of callipers, and tape measures. Based on these measurements, the total log volume, lumber volume, sawed wood yield and log conicity were determined using the methodologies and calculations described below.

First, the volume of logs with bark was obtained, whose calculations are broken down in Equation 1. After the splitting of each log, the length, width and thickness of the piece were measured, using a precision measuring 10 millimeters. All the data were marked in a field worksheet and later used in Equation 2, to determine the individual volume of the sawed pieces. The final volume of lumber was determined according to the Equation 3. The coefficient of volumetric yield (yield of sawn wood) was calculated according to Equation 4. Conicity was calculated according to Equation 6.

$$
\begin{aligned}
& \mathrm{V}_{\mathrm{T}}=\frac{\pi \cdot \mathrm{L}_{\mathrm{T}}}{8}\left(\mathrm{D}_{1}^{2}+\mathrm{D}_{2}^{2}\right) \\
& \mathrm{V}_{\mathrm{PS}}=\mathrm{C} \cdot \mathrm{L} \cdot \mathrm{E} \\
& \mathrm{V}_{\mathrm{MS}}=\sum \mathrm{V}_{\mathrm{PS}} \\
& \mathrm{CR}_{\mathrm{MS}}=\frac{\mathrm{V}_{\mathrm{MS}}}{\mathrm{V}_{\mathrm{T}}} \cdot 100 \\
& \mathrm{RE}=100-\mathrm{CR}_{\mathrm{MS}}
\end{aligned}
$$




$$
\mathrm{C}_{\mathrm{T}}=\frac{\left(D_{2}-D_{1}\right)}{L}
$$

Where: $\mathrm{V}_{\mathrm{T}}=\log$ volume $\left(\mathrm{m}^{3}\right) ; \mathrm{D}_{1}=$ Mean diameter of smallest cross section of the $\log (\mathrm{m}) ; \mathrm{D}_{2}=$ Mean diameter of largest cross section of the $\log (\mathrm{m}) ; \mathrm{L}_{\mathrm{T}}=\mathrm{Log}$ length $(\mathrm{m}) ; \mathrm{V}_{\mathrm{PS}}=$ Piece volume $\left(\mathrm{m}^{3}\right) ; \mathrm{C}=$ Piece length (m); $\mathrm{L}=$ Piece width (m); $\mathrm{E}=$ Piece thickness (m); $\mathrm{V}_{\mathrm{MS}}=$ Final volume of lumber $\left(\mathrm{m}^{3}\right)$. CRMS = coefficient of volumetric yield $(\%)$; $\mathrm{V}_{\mathrm{T}}=\mathrm{Log}$ volume $\left(\mathrm{m}^{3}\right) ; \mathrm{RE}=$ Residues volume $(\%) ; \mathrm{C}_{\mathrm{T}}=\mathrm{Log}$ conicity $(\%) ; D_{1}=$ Mean diameter of smallest cross section of the $\log (\mathrm{m}) ; \mathrm{D}_{2}$ $=$ Mean diameter of largest cross section of the $\log (\mathrm{m})$.

\subsection{Statistical analysis}

The collected data were analysed by applying beta regression according to the methodology proposed by CribariNeto; Cribari-Neto; Souza (2013); Silva; Souza (2014), since the volumetric yield of sawn wood was obtained as percentage values. This model was originally proposed by Ferrari; Cribari-Neto (2004) to estimate results within the interval between zero and one $(0,1)$ by means of a regression structure that contains a link function, covariables and unknown parameters. Thus, in this study, conicity and wood species were used as covariables together with logit (logistical function), probit (normal function) and loglog (normal function logarithm) where the lumber yield was the response variable. The beta regression model assumes that the mean satisfies the functional relationship contained in equation 7 .

$$
g\left(\mu_{\mathrm{i}}\right)=\beta_{0}+\sum_{\mathrm{j}=1}^{\mathrm{k}} \mathrm{X}_{\mathrm{ij}} \beta_{\mathrm{j}}=\eta_{\mathrm{i}} \quad \text { (Equation 7) }
$$

Where: $g\left(\mu_{\mathrm{i}}\right)=$ link function; $\beta_{0}=$ Intercept; $\beta_{\mathrm{j}}=$ vector of unknown regression parameters; $X_{i j}=$ observations of the covariables; $k=$ Number of covariables; $i=$ number of observations; $j=$ covariable index; $\eta_{i}=$ linear predictor.

The combination of the two covariables with the three linking functions resulted in three simple models and three complete ones. In the simple models, the yield was based exclusively on conicity, while in the complete models the yield was based on conicity and wood species. The computational procedure was performed in software $\mathrm{R}$ (R DEVELOPMENT CORE TEAM, 2014), using the "betareg" module developed by Cribari-Neto; Zeleis (2010). The choice of the best was made based on the coefficients given by the program itself and on the analytical and graphic processing of residues. After selecting the model, a quantile-quantile diagram (Q-Q plot) was prepared, where the bisector and bands for the $95 \%$ confidence interval were included.

\section{RESULTS}

Table 2 shows the average values obtained for the volume of logs, sawn wood of the 19 processed species, as well as the percentage of the yield of lumber, residues and the conicity.

Table 3 shows the results corresponding to the evaluation elements of the models for each linking function. The fundamentals used were the coefficient of precision $(\Phi)$, the pseudo coefficient of determination $\left(\mathrm{R}^{2}\right)$ and the Akaike Information Criterion (AIC) provided by $\mathrm{R}$ programming. In addition, this Table contains the median absolute deviation (MAD), mean squared error (MSE), root-mean-square error (RMSE) and the mean absolute percentage error (MAPE).

Table 2. Volumetric and average yield of sawn wood for the studied species.

Tabela 2. Volumetria e rendimento médio em madeira serrada para as espécies estudadas.

\begin{tabular}{lccccc}
\hline \multirow{2}{*}{ Species } & \multicolumn{3}{c}{ Mean Volume $\left(\mathrm{m}^{3}\right)$} & \multicolumn{3}{c}{ Mean $(\%)$} \\
\cline { 2 - 6 } & LO & SW & CR & RE & CO \\
\hline P. reticulata & 1.07 & 0.48 & 44.80 & 55.20 & 1.54 \\
T. burserifolia & 1.44 & 0.71 & 48.01 & 51.99 & 1.40 \\
H. petraeum & 2.70 & 1.41 & 51.78 & 48.22 & 1.48 \\
P. pendula & 1.65 & 0.84 & 50.36 & 49.64 & 1.27 \\
P. multijuga & 1.72 & 0.85 & 48.97 & 51.03 & 1.14 \\
G. polymorpha & 1.69 & 0.84 & 50.08 & 49.92 & 1.04 \\
A. canelilla & 2.15 & 1.19 & 52.77 & 47.23 & 0.86 \\
N. membranacea & 1.45 & 0.74 & 50.01 & 49.99 & 1.03 \\
E. uncinatum & 1.63 & 0.82 & 50.13 & 49.87 & 1.21 \\
C. catenaeformis & 1.96 & 0,89 & 44.77 & 55.23 & 2.46 \\
D. odorata & 1.32 & 0.66 & 49.68 & 50.32 & 1.07 \\
C. multijuga & 1.20 & 0.60 & 48.99 & 51.01 & 1.08 \\
A. hasslerii & 1.49 & 0.74 & 49.36 & 50.64 & 1.04 \\
P. dubium & 0.95 & 0.43 & 44.94 & 55.06 & 1.30 \\
A. Ieiocarpa & 1.90 & 0.96 & 50.17 & 49.83 & 1.40 \\
C. brasiliense & 0.98 & 0.43 & 43.87 & 56.13 & 1.94 \\
M. itauba & 1.25 & 0.61 & 47.86 & 52.14 & 1.53 \\
Q. albiflora & 1.66 & 0.77 & 44.80 & 55.20 & 2.11 \\
G. glabra & 1.24 & 0.60 & 46.83 & 53.17 & 1.26 \\
\hline
\end{tabular}

Legend: LO: Logs; SW: Sawn wood; CR: Volumetric yield; RE: Residues; CO: Conicity.

Table 3. Results of evaluation criteria for each developed model.

Tabela 3. Resultados dos critérios de avaliação para cada modelo.

\begin{tabular}{ccccccccc}
\hline Model & Linking function & $(\Phi)$ & $\mathrm{R}^{2}$ & AIC & MAD (-) & MSE (-) & RMSE (-) & MAPE (\%) \\
\hline \multirow{3}{*}{ Yield=f(conicity) } & logit & $369.00^{* * *}$ & 0.64 & -758.02 & 0.021 & 0.001 & 0.026 & 4.437 \\
& probit & $369.19^{* * *}$ & 0.64 & -758.10 & 0.021 & 0.001 & 0.026 & 4.435 \\
& $\log \log$ & $370.81^{* * *}$ & 0.64 & -758.84 & 0.021 & 0.001 & 0.026 & 4.428 \\
\hline \multirow{2}{*}{ Yield=f(conicity, } & logit & $722.58^{* * *}$ & 0.81 & -836.93 & 0.015 & 0.000 & 0.018 & 3.141 \\
species) & probit & $724.11^{* * *}$ & 0.82 & -837.29 & 0.015 & 0.000 & 0.018 & 3.137 \\
& $\log \log$ & $743.45^{* * *}$ & 0.87 & -841.79 & 0.015 & 0.000 & 0.018 & 3.069 \\
\hline
\end{tabular}

The coefficient values calculated for the intercept, conicity and wood species, as well as the main statistics to evaluate their corresponding significance are shown in Table 4. This Table shows that the conicity presented a marked negative influence on the volumetric yield; that is, the more conical the logs are, the lower the yield of sawn wood will be. In addition, it is noted that the Copaifera multijuga, Albizia hasslerii,
Peltophorum dubium, Calophyllum brasiliense and Goupia glabra species did not interfere significantly in the volumetric yield. However, the Hymenolobium petraeum, Parkia pendula, Gochnatia polymorpha, Aniba canelilla, Nectandra membranacea, Apuleia Ieiocarpa, Mezilaurus itauba and Qualea albiflora species did contribute considerably in increasing the yield. The other species showed little influence 
(Table 4). Figure 1 presents the quantile-quantile distribution diagram with the standardized residues according to the theoretical values, the bisector and the $95 \%$ confidence interval bands. The Figure shows that the residues are close to the bisector and that all of them remained within the referred bands. These characteristics also prove that beta regression calculates the yield of sawn wood according to the conicity and species with adequate precision.

Table 4. Model coefficients and main statistics provided by the $\mathrm{R}$ software for selected model.

Tabela 4. Coeficientes do modelo e principais estatísticas fornecidos pelo Programa R para o modelo selecionado.

\begin{tabular}{|c|c|c|c|c|c|}
\hline Coefficients & Estimate & Standard Error & z value & Probability & Significance \\
\hline Intercept & 0.481334 & 0.021004 & 22.916 & $<2 \mathrm{e}-16$ & $* * *$ \\
\hline Conicity & -0.170606 & 0.008125 & -20.999 & $<2 \mathrm{e}-16$ & $* * *$ \\
\hline Trattinickia burserifolia & 0.067458 & 0.024214 & 2.786 & 0.005339 & $* *$ \\
\hline Hymenolobium petraeum & 0.191096 & 0.024628 & 7.759 & $8.54 \mathrm{e}-15$ & $* * *$ \\
\hline Parkia pendula & 0.113088 & 0.024541 & 4.608 & $4.06 \mathrm{e}-06$ & $* * *$ \\
\hline Parkia multijuga & 0.049651 & 0.024513 & 2.026 & 0.042815 & $*$ \\
\hline Gochnatia polymorpha & 0.112635 & 0.025346 & 4.444 & $8.84 \mathrm{e}-06$ & $* * *$ \\
\hline Aniba canelilla & 0.157990 & 0.025170 & 6.277 & $3.45 \mathrm{e}-10$ & $* * *$ \\
\hline Nectandra membranacea & 0.095115 & 0.024569 & 3.871 & 0.000108 & $* * *$ \\
\hline Erisma uncinatum & 0.059053 & 0.024654 & 2.395 & 0.016610 & $*$ \\
\hline Cedrelinga catenaeformis & 0.062299 & 0.024737 & 2.518 & 0.011788 & $*$ \\
\hline Dipteryx odorata & 0.062711 & 0.024711 & 2.538 & 0.011157 & $*$ \\
\hline Copaifera multijuga & 0.040066 & 0.024575 & 1.630 & 0.103028 & \\
\hline Albizia hasslerii & -0.036075 & 0.023973 & -1.505 & 0.132365 & \\
\hline Peltophorum dubium & 0.044579 & 0.024667 & 1.807 & 0.070721 & . \\
\hline Apuleia Ieiocarpa & 0.130154 & 0.024455 & 5.322 & $1.03 \mathrm{e}-07$ & $* * *$ \\
\hline Calophyllum brasiliense & 0.045803 & 0.024152 & 1.896 & 0.057904 & . \\
\hline Mezilaurus itauba & 0.085885 & 0.024195 & 3.550 & 0.000386 & $* * *$ \\
\hline Qualea albiflora & 0.098986 & 0.024457 & 4.047 & $5.18 \mathrm{e}-05$ & $* * *$ \\
\hline Goupia glabra & 0.010557 & 0.024162 & 0.437 & 0.662164 & \\
\hline
\end{tabular}

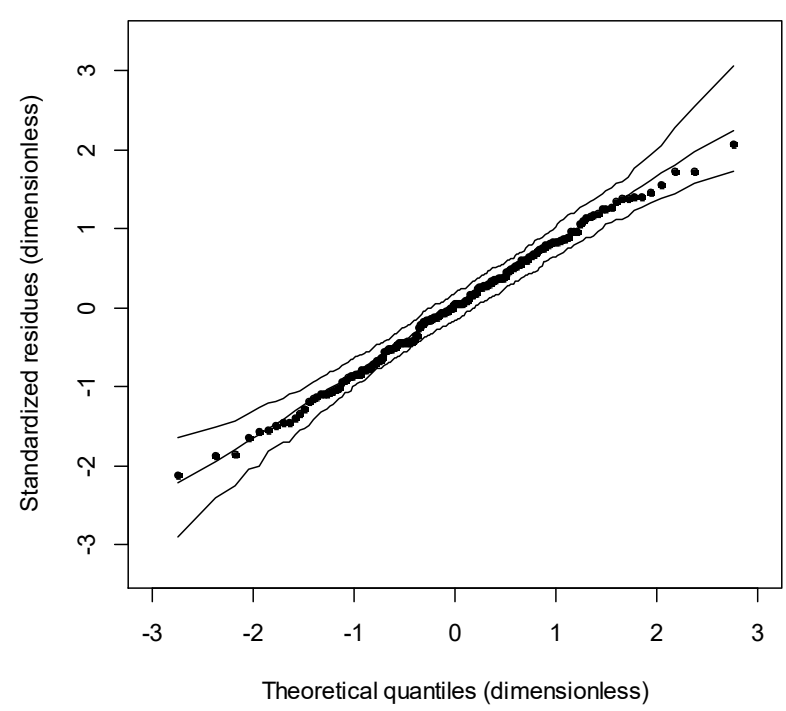

Figure 1. Quantile-quantile diagram with standardized residues as function of the theoretical values, a bisector and the $95 \%$ confidence interval bands.

Figura 1. Diagrama quantil-quantil com os resíduos padronizados em função dos valores teóricos, a bissectriz e as bandas do intervalo de confiança para $95 \%$.

\section{DISCUSSION}

The joint analysis of the data shows that all species presented a yield of more than $35 \%$ of lumber, which is the parameter required by CONAMA 474 (BRASIL, 2016) for native wood. The individual analysis of the species showed that the Aniba canelilla species had the highest percent yield $(52.76 \%)$ and the Calophyllum brasiliense species had the lowest yield (43.87\%).

Biasi; Rocha (2007), while working with wood from Amazonia, found that the yield of the Erisma uncinatum species 59.30\%, Gochnatia polymorpha $62.63 \%$ and
Mezilaurus itauba $53.90 \%$, results which are higher than those obtained in this research. This difference in yield could have probably been caused by the size of the logs which, being native species, showed considerable dissimilarities in their diameter and length measurements.

Garcia (2013) conducted his work on native species in the municipality of Alta Floresta-MT obtained a mean yield of sawn wood of $48.90 \%$ for the Gochnatia polymorpha species, a result that is very close to the one found in this study, which was $47.42 \%$.

The works of Tonini; Ferreira (2004) report yields of sawn timber for the Hymenolobium petraeum species as $66.20 \%$. This value was well above the one found in this research, which was $41.82 \%$ for this species. On the other hand, the same authors reported yield values of sawn wood for the Goupia glabra species (51.93\%) which was close to the values found in this study for the same species $(49.63 \%)$.

In comparison, the work of Oliveira et al. (2003) conducted in the district of Jauru-MT on native species reported a higher yield (49.50\%) for the Hymenolobium petraeum Ducke than that found in this study $(41.82 \%)$. In the case of Cumaru, the yield was also higher $(62.01 \%)$ than the value found in this study (46.20\%). For the Garapa forest species, the yield of sawn wood obtained by the same authors was $48.96 \%$ while the one in this work for this species was $47.64 \%$.

Angelo et al. (2004) carried out their studies in the municipality of Sinop - MT on 11 species common to this study and obtained yield values for sawn wood higher than those found in the present research, yet very close. The results of the sawn wood yield of native species studied by the authors mentioned above were: Trattinickia burserifolia (60.00\%), Hymenolobium petraeum $(55.90 \%)$, Parkia pendula (55.00\%), Gochnatia polymorpha (54.30\%), Nectandra membranacea (57.50\%), Erisma uncinatum (56.70\%), Dipteryx odorata (55.20\%), Albizia hasslerii (52.50\%), 
Apuleia Ieiocarpa (45.40\%), Mezilaurus itauba (49.10\%) e Cupiúba (61.90\%). For comparative purposes, the results of sawn wood yield for the same 11 species raised in our research were: Trattinickia burserifolia (53.80\%), Hymenolobium petraeum (41.82\%), Parkia pendula (38.41\%), Gochnatia polymorpha (47.42\%), Nectandra membranacea (50.69\%), Erisma uncinatum (56.01\%), Dipteryx odorata (46.20\%), Albizia hasslerii (44.71\%), Apuleia Ieiocarpa (47.64\%), Mezilaurus itauba (47.00\%), Cupiúba (49.63\%).

In terms of comparison, the average yield of $48.32 \%$ for sawn wood at the sawmill under study was next to the value found by Mendoza et al. (2017), who reported values of $47.48 \%$ of yield when working with native wood from the state of Mato Grosso. However, was higher than the value described in the works of Garcia et al. (2012), which obtained a 40\% yield for a sawmill in the city of São Gabriel, RS. In contrast, the yield value of the sawmill under study was lower than the values reported by Oliveira et al. (2003), who verified a yield of $49.28 \%$ for sawmills in the city of Jaru - RO while working with native species of the Amazon. The yield value of $48.32 \%$ was also lower than that reported by Angelo et al. (2004), who reported a $54.85 \%$ yield for sawmills in the municipality of Sinop-MT, when using wood native to the Amazon.

Conicity is characterized by the decrease in the diameter along the shaft of the tree from the base to the crown (SCOLFORO, 1998). The ideal shape of the trunk is cylindrical, but conicity is a normal feature in trees mainly due to the nature of their growth and to genetic factors. According to Murara Junior et al. (2013) conicity is an extremely important factor in evaluating the quality of a log to be sawn, since the yield of sawn wood is directly related to this factor. Vital (2008) supports this idea, mentioning that the index of volumetric transformation, which is the ratio between the volume of lumber and the volume of logs, is highly influenced by the log's conicity.

The joint analysis of the data shows that all species presented a yield of more than $35 \%$ of lumber, which is the parameter required by CONAMA 474 (BRASIL, 2016), for native wood and conicity of less than $3 \%$, which is one of the criteria for logs established by the IBDF (1984), to determine the quality of logs.

Cerqueira et al. (2012) state that the logs' quality influences the sawmill's production process, since all sawing decisions are made based on the visual quality presented by the logs, and this can affect the sawmill's net yield.

According to Campos et al. (2014), the relationship between two different variables shows how close these variables are. Therefore, the conicity, being the variation of the diameter along the trunk, was adopted as an evaluation index of the shape of the logs, as proposed by Vital (2008); Carvalho et al. (2010); Lanssanova et al. (2013); Schröder et al. (2013), and adequately served as input variable in the proposed model to estimate the yield of sawn wood.

Garcia et al. (2012), as they analysed the yield of sawn wood from two species from the Amazon region (Couratari guianensis and Mezilaurus itauba), concluded that the quality of the log, especially its conicity, may or may not interfere with the yield and that this depended on the species being processed.

The complete models obtained in this study, that included the species as covariables, presented good evaluation criteria. The better performance was mainly evidenced by the values of the mean absolute percentage error (MAPE), which lower than
4\%. Among these, the Lognormal model (loglog) was also superior (Table 3), as it showed the best results for $\Phi, \mathrm{R}^{2}$ and AIC. This characteristic justifies the application of the beta regression models by using the mentioned link function, since this distribution provides a more accurate representation of the yield values of the logs, considering both conicity and species as can be confirmed in Figure 1.

Lanssanova et al. (2013), they mention that linear regression models are appropriate to represent the relationship between volumetric yield and log conicity. However, the author did not identify the individual contribution of each species in the model. The use of beta regression in this study allowed such identification thus contributing in a precise way to the interpretation of results and shows an adequate performance of the model.

Danielli et al. (2016), while modelling the yield sawing logs of maçaranduba (Manilkara ssp.) obtained a determination coefficient around 0.80 for a nonlinear regression by considering the volume and the fine tip diameter. However, a high residue value was verified, which reduces the accuracy and reliability of the models. In the present study, the beta regression model explains over $85 \%$ of the yield in sawn wood and the values of the residues were low. These characteristics indicate that such regression provided an appropriate adjustment of the data.

Santos et al. (2017), also emphasize in their research the importance of using precision statistics, showing satisfactory results when working with mathematical modeling, to estimate the yield of sawn wood of the species Dinizia excelsa and Manilkara huberi, from the state of Amapá, using in its models, only the total volume of the $\log$, as input of the response variable.

\section{CONCLUSIONS}

The studied species presented a yield higher than the minimum required by the current legislation. A precise statistical model was developed to calculate the yield in sawn wood, according to conicity and species. The mathematical relation, obtained by the beta regression, used to estimate the volumetric yield of sawn wood as a function of conicity and the species, showed adequate reliability, which justifies its application. The inclusion of the species in the referred model increased significantly its precision. Thus, the proposed statistical model made it possible to previously calculate the volume of sawn wood, an estimate which can be obtained totally or individually, before the processing of the logs. In addition, it can be a useful tool for planning and managing the processing of logs from the Legal Amazon, helping in the decision making for the conscious use of this renewable resource.

\section{REFERENCES}

ÂNGElO, H.; SILVA, G. F.; SILVA, V. S. M. Análise econômica da indústria de madeiras tropicais: $\mathrm{O}$ caso do polo de Sinop, MT. Ciência Florestal, Santa Maria, v. 14, n. $2, \quad$ p. 95-96, 2004. DOI: http://dx.doi.org/10.5902/198050981809

BIASI, C. P.; ROCHA, M. P. Rendimento em madeira serrada e quantificação de resíduos para três espécies tropicais. Revista Floresta, Curitiba, v. 37, n. 1, p. 95-108, 2007. DOI: http://dx.doi.org/10.5380/rf.v37i1.7845

BUFALINO, L.; PROTÁSIO, T. P.; COUTO, A. M. NASSUR; O. A. C.; SÁ, V. A.; TRUGILHO, P. F.; 
MENDES, L. M. Caracterização química e energética para aproveitamento da madeira de costaneira e desbaste de cedro australiano. Pesquisa Florestal Brasileira, Colombo, v. 32, n. 70, p. 129-137, 2012. DOI: http://dx.doi.org/10.4336/2012.pfb.32.70.13

BRASIL. CONSELHO NACIONAL DO MEIO AMBIENTE (CONAMA). Resolução No 411, de 6 de maio de 2009. Diário Oficial da República Federativa do Brasil n⿳0 86, Brasília, DF, p. 93-96, 2009.

BRASIL. MINISTÉRIO DO MEIO AMBIENTE (MMA). CONSELHO NACIONAL DO MEIO AMBIENTE (CONAMA). Resolução $\mathrm{n}^{\circ}$ 474, de 6 de abril de 2016. Diário Oficial da República Federativa do Brasil no 82 , Brasília, DF, Seção 1, p. 74-75, 2016.

CAMPOS B. P. F.; BINOTI, D. H. B.; SILVA, M. L.; LEITE, H. G.; BINOTI, M. L. M. S. Efeito do modelo de afilamento utilizado sobre a conversão de fustes de árvores em multiprodutos. Scientia Forestalis, Piracicaba, v. 42, n. 104, p. 513-20, 2014.

CARVALHO, S. P. C.; MENDONÇA, A. R.; LIMA, M. P.; CALEGARIO, N. Different strategies to estimate the commercial volume of Anadenanthera colubrina (Vell.) Brennan. Cerne, v. 16, n. 3, p. 399-406, 2010. DOI: http://dx.doi.org/10.1590/S0104-77602010000300016

CERQUEIRA, P. H. A; VIEIRA, G. C.; BARBERENA, I. M.; MELO, L. C.; FREITAS, L. C. Análise dos Resíduos Madeireiros Gerados Pelas Serrarias do Município de Eunápolis-BA. Floresta e Ambiente, Seropédica, v.19, n. 4, p. 506-510, 2012. DOI: http://dx.doi.org/10.4322/floram.2012.051

CRIBARI-NETO, F.; SOUZA, T. C. Religious belief and intelligence: Worldwide evidence. Intelligence, v. 41, 482-489, 2013.

CRIBARI-NETO, F.; SOUZA, T. Testing inference in variable dispersion beta regressions. Journal of Statistical Computation and Simulation, v. 82, n. 12, p. 1827-1843, 2012. https://doi.org/10.1080/00949655.2011.599033

CRIBARI-NETO, F.; ZEILEIS, A. Beta Regression in R. Journal of Statistical Software, Londres, v. 34, p. 1-24, 2010.

DANIELLI, F. E.; GIMENEZ, B. O.; OLIVEIRA, C. K. A.; SANTOS, J.; HIGUCHI, N. Modelagem do rendimento no desdobro de toras de Manilkara spp. (Sapotaceae) em serraria do estado de Roraima, Brasil. Scientia Forestalis. Piracicaba, v. 44, n. 111, p. 641-651, 2016.

FERRARI, S. L. P.; CRIBARI-NETO, F. Beta regression for modeling rates and proportions. Journal of Applied Statistics, Londres, v. 31, p.799-815. 2004. DOI: https://doi.org/10.1080/0266476042000214501

GARCIA, F. M.; MANFIO, D. R.; SANSÍGOLO, C. A.; MAGALHÃES, P. A. D. Rendimento no desdobro de toras de itaúba (Mezilaurus itauba) e tauari (Couratari guianensis) segundo a classificação da qualidade da tora. Floresta e Ambiente, Seropédica, v. 19, n. 4, p. 468-474, 2012. DOI: http://dx.doi.org/10.4322/floram.2012.059

GARCIA, F. M. Rendimento operacional de uma serraria com a espécie Cambará (Qualea albiflora Warm) na região amazônica. 2013.155f. Dissertação (Mestrado em Ciências Florestais) - Universidade Estadual Paulista Júlio de Mesquita Filho, Botucatu, 2013.

IBDF_INSTITUTO BRASILEIRO DE DESENVOLVIMENTO FLORESTAL. Norma para medição e classificação de toras de madeiras de folhosas. Brasília: Brasiliana, 1984. 42p.

JUIZO, C. G. F.; ROCHA, M. P.; BILA, N. F. Avaliação do rendimento em madeira serrada de eucalipto para dois modelos de desdobro numa serraria portátil. Floresta e Ambiente, Seropédica, v. 21, n. 14, p. 543-550, 2014. DOI: http://dx.doi.org/10.1590/2179-8087.062213

LANSSANOVA, L. R.; UBIALLI, J. A.; ARCE, J. E.; PELISSARI, A. L.; FAVALESSA, C. M. C.; DRESCHER, R. Avaliação de funções de afilamento para espécies florestais comerciais do bioma amazônico matogrossense. Revista Floresta, Curitiba, v. 43, n. 2, p. $215-$ 224, 2013. DOI: http://dx.doi.org/10.5380/rf.v43i2.26518

LORENZI, H. Árvores brasileiras: manual de identificação e cultivo de plantas arbóreas do Brasil. 5. ed., Nova Odesa: Instituto Plantarum, 2008. 384 p. v. 2.

MELO, L. E. L.; SILVA, C. J.; LOPES, K. V.; BRITO, P. G. M.; SANTOS, I.S. Resíduos de Serraria no Estado do Pará: Caracterização, Quantificação e Utilização Adequada. Floresta e Ambiente, Seropédica, v. 19, n. 1, p. 113-116, 2012. DOI: http://dx.doi.org/10.4322/floram.2012.012

MENDOZA, Z. M. S. H.; EVANGELISTA, W. V.; ARAÚJO, S. O.; SOUZA, C. C.; RIBEIRO, F. D. L.; SILVA, C. J. Análise dos resíduos madeireiros gerados nas marcenarias do município de Viçosa - Minas Gerais. Revista Árvore, Viçosa, v.34, n.4, p.755-760, 2010. DOI: http://dx.doi.org/10.1590/S0100-67622010000400020

MENDOZA, Z. M. S. H.; BORGES, P. H. M.; PIERIN, L. C. Coeficiente de rendimento em madeira serrada de oito espécies nativas de Mato Grosso. Nativa, Sinop, v. 5, esp., p. 568-573, dez. 2017. DOI: http://dx.doi.org/10.5935/2318-7670.v05nespa16

MURARA JUNIOR, M. I.; ROCHA, M. P.; TRUGILHO, P. F. Estimativa do Rendimento em Madeira Serrada de Pinus para duas Metodologias de Desdobro. Floresta e Ambiente, Seropédica, v.20, n.4, p.556-563, 2013. DOI: http://dx.doi.org/10.4322/floram.2013.037

OLIVEIRA, A. D.; MARTINS, E. P.; SCOLFORO, J. R.; REZENDE, J. L.; SOUZA, A. N. Viabilidade econômica de serrarias que processam madeira de Florestas Nativas O caso do município de Jaru, Estado de Rondônia. Cerne, Lavras, v. 9, n. 1, p. 6-7, 2003.

$\mathrm{R}$ Development Core Team. A language and environment for statistical computing, $\mathrm{R}$ Foundation for Statistical Computing, Vienna, Available at: http://www.Rproject.org/

SANTOS, R. O.; ARAÚJO, C. C. S.; TAVARES, H. V. B.; SILVA, D. A.; OLIVEIRA, C. P.; LIMA, R. B. Modelagem do rendimento em madeira serrada para espécies comerciais em serrarias do estado do Amapá. Nativa, Sinop, v. 5, esp., p. 612-618, dez. 2017. DOI: http://dx.doi.org/10.5935/2318-7670.v05nespa23

SCHRÖDER, T.; HOFIÇO, N. A. S.; ZIMMERMANN, A. P. L.; PEREIRA, L. C.; ROCHA JUNIOR, D. S.; MEYER, E. A.; FLEIG, F. D. Métodos de estimativa de volume comercial para Eucalyptus grandis: especificidades e recomendações. Pesquisa Florestal Brasileira. Colombo, v. 33, n. 73, p.01-07, 2013. DOI: https://doi.org/10.4336/2013.pfb.33.73.446

SCOLFORO, J. R. S. Biometria florestal: medição e volumetria de árvores. Lavras: UFLA/FAEPE, 1998. 310 p. 
SILVA, C.; SOUZA, T. Modelagem da taxa de analfabetismo no estado da Paraíba via modelo de regressão beta. Revista Brasileira de Biometria, Lavras, v. 32, n. 3, p. 345-359, 2014.

TONINI, H.; FERREIRA, L. M. Rendimento em madeira serrada de cupiúba (Goupia glabra), caferana (Erisma uncinatum) e angelim-pedra (Dinizia excelsa). Boa Vista: Embrapa Roraima, 2004. 6p. (Comunicado Técnico 7).

VITAL, B. R. Planejamento e Operação de Serrarias. Viçosa: Editora UFV, 2008. 211 p. 